\title{
"Dios hizo el mundo en una semana / pero yo lo destruyo en un momento": la desacralización del texto bíblico en la poesía de Nicanor Parra
}

\author{
Lorena FERRER REY \\ Universidad Complutense de Madrid \\ lorenaferrerrey@gmail.com
}

\begin{abstract}
RESUMEN
El presente artículo expone las analogías existentes entre la poesía de Nicanor Parra y una de sus fuentes más fructíferas: la Biblia. El diálogo que los versos del chileno mantienen con el libro sagrado del judeocristianismo está revestido, sin embargo, de subversión: la atención que Parra le ha prestado a lo largo de su obra al texto bíblico toma la forma de una desacralización, encaminada a dinamitar un grandísimo relato de la humanidad y borrar la credibilidad de la cual este ha gozado durante tantos siglos. Su antipoesía arremete contra toda imposición política o ideológica y de ahí procede la utilización iconoclasta del intertexto bíblico, que, ya en términos sarcástico-humorísticos, ya con una visión más pesimista, insta a sus lectores a tomar conciencia.
\end{abstract}

Palabras clave: Nicanor Parra, Biblia, religión, posmodernidad, antipoesía

\begin{abstract}
This article intends to present the existing analogies between Nicanor Parra's poetry and the Bible, which is one of its most fruitful sources. The dialogue that his verses establish with the holy book of Judeo-Christianity, however, is filled with subversion: the attention that Parra has granted to the biblical text throughout his work takes the shape of a demystification, aiming to wipe out a "grand narrative" of humanity and to erase the credibility that it had enjoyed over centuries. His antipoetry attacks every political or ideological imposition, what results in the iconoclastic use of the biblical intertext, which, either in satiric-humoristic terms or from a more pessimistic point of view, instigates his readers to become aware.
\end{abstract}

Keywords: Nicanor Parra, Bible, religion, postmodern condition - antipoetry

Sumario: 1. Introducción, 2. Las máscaras: "Yo, Jehová" y el Cristo de Elqui, 3. Antiguo Testamento vs. Nuevo Testamento, 4. De crucifixiones, crucificados y cruces, 5. "Pater noster, qui es in caelis..." 


\section{Introducción}

Dos anecdóticas declaraciones - a las que llegué, como solo se puede llegar a estos curiosos descubrimientos, de casualidad - inspiran y alientan el presente trabajo. La primera: en una entrevista publicada en el diario chileno La Nación, el poeta Raúl Zurita hablaba de la vinculación entre poesía y pensamiento divino existente en la obra de sus compatriotas o de otras grandes voces de la literatura hispanoamericana, para acabar concluyendo que Nicanor Parra es "un poeta católico, pero al revés" 1 . Pocas definiciones resultan más certeras para este adalid del prefijo anti-, con el que decidió coronar su poesía y a sí mismo como poeta. De la segunda declaración no hay más prueba documental que el registro de mi propia memoria: el pasado año en la Librería del Centro, en la presentación de su libro Nicanor Parra y la poética de la veracidad (Madrid, Del Centro Editores, 2012), el crítico Julio Ortega nos contó a los asistentes al acto cómo la última vez que había visitado al poeta chileno en su casa de Tres Cruces lo había hallado traduciendo los Evangelios porque en uno de ellos, según recordó Ortega, podía encontrarse humor.

La atención que Parra le ha prestado a lo largo de su obra, y aún le presta hoy día, al texto bíblico se ve de manera manifiesta en este par de anécdotas, pero, si rastreamos en su poesía, encontraremos muchas más evidencias. La Santa Biblia es, dice nuestro poeta —o, más bien, dice su alter ego, el Cristo de Elqui-, "el único libro verdadero / los demás son hermosos pero falsos" ${ }^{2}$; sin embargo, su afán demoledor lo lleva a darle un giro de $360^{\circ}$. Y es que, como él mismo señala en otro de sus poemas, todo puede probarse con la Biblia, siempre que esta se baraje, se adultere o, llevando la subversión al extremo, se descuartice.

Todo puede probarse con la Biblia
por ejemplo que Dios no existe
por ejemplo que el Diablo manda más
por ejemplo que Dios
es masculino y femenino a la vez
o que la Virgen María era liviana de cascos
basta con conocer un poco el hebreo
para poder leerla en el original e interpretarla
como debe ser es cuestión de análisis lógico
Tienen razón los amigos escépticos
todo puede probarse con la Biblia
es cuestión de saberla barajar
es cuestión de saberla adulterar
es cuestión de saberla descuartizar

${ }^{1}$ La declaración de Zurita ha sido extraídas de: J. García (2010).

${ }^{2}$ Poema LXIII, en Nuevos sermones y prédicas del Cristo de Elqui (1979). Todos los poemas de Parra se citan a partir de los dos tomos de sus obras completas, referenciadas en la bibliografía final: N. Parra (2011), p. 75. 
como quien descuartiza una gallina:

¡pongan otra docena de cervezas! ${ }^{3}$

Este afán subversivo no puede sino enmarcarse dentro de la función que Nicanor Parra le otorga a su poesía-montaña rusa ${ }^{4}$, a su poesía-pinchazo en la médula ${ }^{5}$, a su poesía escrita con la intención de saltar el mundo por los aires y concienciar a quien la lee de dicha destrucción. Los artefactos, una de las expresiones máximas de su obra poética, surgen, según declara, de la explosión del antipoema y, más importante aún, del mundo cultural al que este se refiere:

Bueno, los artefactos son más bien como los fragmentos de una granada. La granada no se lanza entera contra la muchedumbre. Primero tiene que explotar: los fragmentos salen disparados a altas velocidades, o sea, están dotados de una gran cantidad de energía y pueden atravesar entonces la capa exterior del lector. [...] Porque se trata de penetrar, de romper, de sacar al lector de su modorra y pincharlo.

¿Desaparecerá la poesía? Parra no lo cree, ya que esta "está desempeñando ahí una función inmediata, como una fuerza poderosísima. Se refiere a la toma de conciencia del problema". ¿Y cuál es el problema del que el receptor ha de tomar conciencia? Este está intrínsecamente relacionado con el pecado original, que el poeta reformula para adaptarlo a la situación de nuestro contexto contemporáneo: "Nosotros hemos sido expulsados del paraíso y queremos retornar a ese paraíso, y parece que la manera de retornar es precisamente reconstruyendo nuestra imagen inicial. El poeta anda buscando la casa para el hombre actual, que está a la intemperie. La casa vieja se vino al suelo" ${ }^{\prime 6}$. Sin embargo, esta nostalgia de un paraíso perdido no se corresponde con la verdadera creencia en un paraíso bíblico al que el hombre pueda retornar y el poeta tampoco busca el refugio para él en la casa del judeocristianismo, sino que, más bien, se complace en dejarlo aún más a la intemperie demoliendo los escombros de la vieja casa ya derruida.

\footnotetext{
${ }^{3}$ N. Parra (2011), p. 48.

${ }^{4}$ Así la define en el poema "La montaña rusa" de Versos de salón (1962): "Durante medio siglo / la poesía fue / el paraíso del tonto solemne. / Hasta que vine yo / y me instalé con mi montaña rusa”, en N. Parra (2006), p. 86.

5 "Esta noción de pinchazo a la médula es interesante. Se trata de tocar puntos sensibles del lector con la punta de una aguja, de galvanizarlo de manera que el lector mueva un pie, mueva un dedo o gire la cabeza". Palabras en boca de Nicanor Parra que forman parte del libro de L. Morales (1992), p. 100.

${ }^{6}$ Ibíd., p. 101, 129 y 104, respectivamente
} 
La desacralización del discurso bíblico puede insertarse en el marco del "descreimiento posmoderno de los grandes relatos o metarrelatos modernos" , siguiendo lo expuesto por Lyotard en La condición postmoderna: los grandes relatos de la modernidad, que defendían la idea de un progreso hacia el que tendía el curso lineal de la historia, y que requerían de la presencia de un gran narrador, se someten a la incredulidad y se desmiembran o, como sucede en este caso, se desmitifican. Nicanor Parra es un gran destructor de mitos, que cuestiona, principalmente, tres de estos grandes relatos: el cristiano, el marxista y, en menor medida, el capitalista. Dejando los dos últimos al margen, nos centraremos en el primero para ver cómo este descuartizamiento bíblico que Parra lleva a cabo en varios de sus poemas está encaminado a dinamitar un grandísimo relato de la humanidad - que, a diferencia de los otros dos anteriormente mencionados, lleva una andadura más amplia- y borrar la credibilidad de la cual este ha gozado durante tantos siglos.

Antes de entrar en el análisis de sus poemas desacralizadores, considero necesario contextualizar también este discurso desmitificador dentro de la vocación contracultural que Selena Millares reconoce para la antipoesía de Nicanor Parra y define del siguiente modo:

La contracultura es cultura, pero es la cultura de los márgenes, que se rebela contra la oficialidad canónica y dogmática, como la antipoesía es una manifestación de la más legítima poesía, con una gran singularidad que la distingue: su insólita participación simultánea en las formas populares y cultas del discurso, que le otorga un lugar de honor en dos genealogías, la de Golías y la de Blake.

El antipoeta arremete en su obra contra todo orden represivo, contra cualquier imposición política, ideológica o religiosa que conduzca al hombre a la alienación, y de ahí procede "la reacción violenta, la demolición de los lugares totémicos de la civilización occidental, el cuestionamiento de los axiomas más sagrados" ${ }^{\prime 8}$. La obra parriana es, al mismo tiempo, la manifestación de una crisis - ya sea en términos sarcástico-humorísticos, ya con una visión más pesimista y desolada - y la expresión de un compromiso ético y humanista. Parra no se erige como portavoz de ningún nuevo gran relato, sino que su compromiso pasa por destruir las imposturas discursivas que aún quedan en pie y liberar al hombre para que pueda volver a escribirse, y en definitiva a crearse, esta vez sin lastres ni dogmas.

\footnotetext{
${ }^{7}$ N. Binns (1997), p. 193.

${ }^{8}$ S. Millares (2011), p. 84 y 91, respectivamente.
} 


\section{Las máscaras: "Yo, Jehová" y el Cristo de Elqui}

Siguiendo a Lyotard, decíamos antes que todo gran relato necesita su gran narrador, "capaz de comprender, corregir y dominar el universo", mientras que la posmodernidad tiende a la profusión de pequeños discursos, a la fragmentación del sujeto. Nicanor Parra describe este mismo hecho de otro modo, dando cuenta en él de la evolución del sujeto poético dentro de su propia obra:

En la poesía llamada tradicional, la poesía lírica por lo menos, el que habla es siempre el poeta, que se supone es un héroe, un pequeño dios, un sujeto positivo. En seguida vienen los antipoemas en que se trabaja con un antihéroe. Pero este antihéroe todavía es una víctima de las circunstancias. [...] El personaje que se desarrolla después [...] es un sujeto muy estrambótico, muy extravagante [...], este es un sujeto eminentemente activo, capaz de desarrollar grandes cantidades de energía [...] Bueno, el personaje ya está disociado y por eso no presenta una sola cara, sino que es una especie de camaleón, una especie de hombre múltiple. No hay una unidad psicológica para empezar. El sujeto no está integrado psicológicamente: está fuera de sí. Esa es la condición básica del energúmeno: estar fuera de sí. Etimológicamente es un poseído, o sea, no responde de sus actos, habla por boca de ganso o por boca de Lucifer. Es Lucifer quien habla a través de él. ${ }^{10}$

El personaje múltiple en boca del cual está la poesía de Parra dinamita la subjetividad tradicional y adopta múltiples máscaras, metamorfoseándose en varias dramatis personae. Dos de ellas responden a nuestros intereses: en primer lugar, el "Yo, Jehová" que enuncia al comienzo de dos poemas de su libro Emergency poems (1972): "En vista y considerando" y "Yo Jehová decreto"; en segundo lugar, el particular Cristo de Elqui, sujeto protagonista de los poemarios Sermones y prédicas del Cristo de Elqui (1977) y Nuevos sermones y prédicas del Cristo de Elqui (1979), cuyo nombre revela la vinculación con el discurso religioso, aún más sui géneris de lo que cabría esperar.

Empecemos, con el Génesis, dando cuenta de la creación del mundo: "Dijo Dios: «Haya luz». Y hubo luz" (Gen 1, 3). En un arranque de descaro, Parra transforma la tercera persona que da cuenta de lo creado por el protagonista indiscutible del inicio de los tiempos, Dios-Yahveh-Elohim-Jehová, en una primera persona que se atreve a enunciar "Yo Jehová decreto que se haga luz" y que no solo lo decreta, lo exige, pues considera que este mismo mandato, enunciado en las Sagradas Escrituras, o bien no se cumplió, o ha sido desatendido en los tiempos modernos por las autoridades eclesiásticas y por la humanidad en general:

ustedes recordarán

que en la Biblia aparezco ordenando lo

\footnotetext{
${ }^{9}$ N. Binns, (1997), p. 24.

${ }^{10}$ Leónidas Morales, op. cit., pp. 106-107.
} 


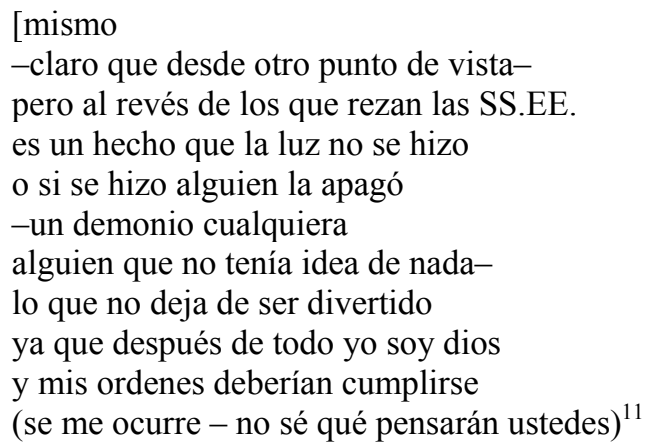

Jehová se dirige a la humanidad para repetir un mensaje que supone olvidado, para subsanar el acto fallido que es, según él, la creación: "yo no voy a cruzarme de brazos / y como un organillero de barrio / repito mi vieja canción". Esta Creación que él escribe con mayúscula inicial, al fin y al cabo es su acto supremo- se presenta como inacabada ("la Creación está por empezar!") y Dios nos habla para, con nuestra ayuda - los sacerdotes y los Padres de la Iglesia le han fallado: ¿a quién puede recurrir ahora sino a nosotros? - la encaucemos hacia buen puerto. El otro poema en boca de Jehová es, sin embargo, mucho más pesimista y de corte más apocalíptico que genesíaco. Si, en el anterior, a Jehová aún le quedaba alguna esperanza de poder arrojar luz sobre lo que sus súbditos habían sumido en las tinieblas, en este, renuncia ante la perspectiva desoladora sobre el mundo que ha creado y que los hombres no dejan de aniquilar. Así, termina el poema advirtiéndolos con una pregunta amenazadora:

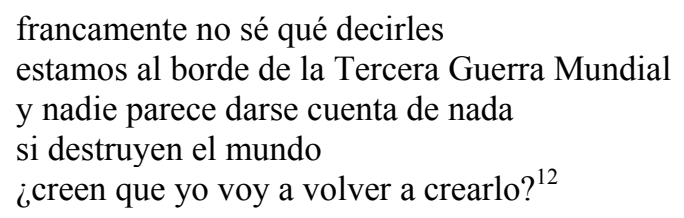

La segunda máscara es la del Cristo de Elqui, más importante a mi parecer porque no se restringe a un par de poemas, sino que vehicula dos libros enteros, en los que Nicanor Parra le rinde homenaje a un personaje que fue histórico antes que literario: Domingo Zárate Vega, un campesino chileno que se postuló casi como mesías y bautizaba a los fieles en el río de Elqui. El poeta decide hablar con sus palabras y transformar así su prédica en poesía. La vinculación de los poemas del Cristo de Elqui con la religión no tiene tanto que ver, entonces, con un parafraseo desmitificador de la Biblia como con la asunción de un tono homílico; se conocen, de hecho,

\footnotetext{
${ }^{11}$ N. Parra (2006), p. 274.

${ }^{12}$ N. Parra (2006), p. 301.
} 
como sermones y prédicas. El poeta declara haberse mostrado, en primera instancia, escéptico ante este tipo de discurso, pero poco a poco se va impregnando de él y sintiéndose más cómodo en su nuevo ro ${ }^{13}$.

Las razones que llevan a la elección de este sujeto poético están relacionadas con la búsqueda de una vía de escape después del golpe militar. Los poemarios del Cristo de Elqui son los primeros que Parra escribe una vez iniciada la dictadura y en ellos escoge retrotraerse a los años 30 para, desde la voz de un personaje relativamente alejado de su propio contexto, denunciar el momento presente. El individuo fragmentario hacia el que había ido evolucionando su voz poética reunifica sus piezas y las cohesiona en la voz única del predicador, que trae un hilarante mensaje de paz a los tiempos venideros, es decir, al Chile de finales de los setenta. La rehumanización que suponen estos dos libros protagonizados por Domingo Zárate, la adopción de esta máscara protectora, tiene, entonces, mucho que ver con las circunstancias políticas y así lo reconoce el propio poeta cuando le preguntan por el viraje en su tipo de discurso poético:

Yo creo que en esto tiene que ver también el golpe militar. Tiene que ver el golpe militar. Porque después del golpe uno se pregunta, bueno, ¿se perdió todo? ¿Se perdió toda posibilidad de discurso tradicional? ¿Todo se va a reducir al lenguaje militar? No, pues. A lo mejor nosotros con restos del discurso tradicional podemos tratar de armar un espantajo. ${ }^{14}$

Bien mirado, tanto Jehová — que, desde los poemas de 1972, preludiaba la debacle chilena acaecida solo un año después- como el Cristo de Elqui - cuyos sermones y prédicas están inmersos ya en ella - son fantoches tras los que se oculta el poeta, y ambos revelan su afán reformador, siempre tratado con humor antes que con solemnidad. Ya utilice un tono sermonal, ya uno divino, Parra se alza como predicador de una "buena nueva" que pretende combatir la crisis que denuncia y, para ello, extrae estas voces del discurso religioso, bíblico o popular, y las transforma acorde con sus propósitos. Un Dios desolado y un predicador convincente son los heraldos de un nuevo mensaje que pretende renovar el mundo, aunque este solo quiera $-\mathrm{y}$, quizá, necesite - saltar en pedazos.

\footnotetext{
13 "Yo cuando me puse a escribir los Sermones, la idea que tenía era que el sermón y la prédica están de más y que es una locura sermonear. Que no se debe hacer, y que en último término es ridículo [...] después de que se hicieron los Sermones y prédicas, me considero en este momento un predicador. Un predicador de la buena nueva que sería la supervivencia", en L. Morales (1992), p. 131.

${ }^{14}$ Ibíd., p. 132.
} 


\section{Antiguo Testamento vs. Nuevo Testamento}

A pesar de que en Emergency poems hallábamos parodiado por partida doble el primer capítulo del Génesis, la poesía de Nicanor Parra manifiesta en general una presencia mayor del Nuevo Testamento que del Antiguo. No podemos olvidar que la demolición de esos discursos dogmáticos se halla más bien relacionada con el cristianismo - y principalmente con el catolicismo, no hay más que ver las críticas al Papa o al clero- que con el judaísmo; Cristo, Marx y Freud son los tres principales cabezas de turco de su sátira poética y hay una "irreverencia constante frente a esas tres figuras sobre las que se sustenta el pensamiento de Occidente" ${ }^{\prime 5}$. Ello no es obstáculo, sin embargo, para que algunos de los poemas parrianos tengan su inspiración en pasajes del Antiguo Testamento. He ahí, por ejemplo, el llamado "Las tablas", incluido en Poemas y antipoemas (1959), un poema narrativo de corte onírico en el que al sujeto poético se le aparecen las tablas de la ley después de haber transgredido el quinto mandamiento, aquel que reza lo siguiente: "Honra a tu padre y a tu madre, como te lo ha ordenado Yahveh, tu Dios, para que se prolonguen tus días y seas feliz en el suelo que Yahveh, tu Dios, te da" (Dt 5, 16). Estas le reprenden por su comportamiento y le recuerdan sus pecados.

"Por qué maltratas a tu madre" me preguntaba entonces una piedra

Una piedra cubierta de polvo "por qué la maltratas".

Yo no sabía de dónde venían esas voces que me hacían temblar

Me miraba las uñas y me las mordía,

Trataba de pensar infructuosamente en algo

Pero sólo veía en torno a mí un desierto

Y veía la imagen de ese ídolo,

Mi dios que me miraba hacer estas cosas.

Aparecieron entonces unos pájaros

Y al mismo tiempo en la obscuridad descubrí unas rocas.

En un supremo esfuerzo logré distinguir las tablas de la ley:

"Nosotras somos las tablas de la ley" decían ellas

"Por qué maltratas a tu madre"

"Ves esos pájaros que se han venido a posar sobre nosotras"

"Ahí están ellos para registrar tus crímenes"16

La mención al ídolo en el desierto revela la inspiración de este poema en el pasaje del Éxodo en el que Moisés rompe las tablas de la ley al descubrir el becerro de oro que ha construido el pueblo israelita $-s u$ pueblo - y al cual este idolatra, incumpliendo con ello el segundo de los diez mandamientos dictados por Dios y escritos en dichas tablas: "Cuando Moisés llegó cerca del campamento y divisó el becerro y vio las danzas, encendido en cólera, arrojó de sus manos las tablas y las hizo añicos

\footnotetext{
${ }^{15}$ S. Millares, (2011), p. 89.

${ }^{16}$ N. Parra (2006), p. 59.
} 
al pie del monte. Después tomó el becerro que habían hecho, lo quemó y lo trituró hasta reducirlo a polvo, lo disolvió en agua y se lo hizo beber a todos los israelitas" (Éx 32, 19). En "Las tablas", el sujeto también incinera el busto del dios, pero aquí para lidiar con su propia conciencia, y son las tablas las que desaparecen solas y lo dejan desamparado, sin un asidero divino al que recurrir para redimir sus pecados. El abandono es su castigo: el Dios protector de la Biblia es aquí, y en la posmodernidad, un Dios ausente.

También el motivo del cordero pascual, aquel que los israelitas han de comer en Pascua y con cuya sangre han de rociar el dintel de sus puertas, procede del Antiguo Testamento, por más que su transformación en Agnus Dei lo vincule irremediablemente con el cristianismo. La imagen del Mesías como "cordero de Dios" ya está anticipada en los libros proféticos — según Isaías, este "era maltratado, y él se humillaba y no abría la boca, como cordero llevado al matadero y como oveja muda ante sus esquiladores" (Is 53,6) - , pero esta identidad se refuerza en el Nuevo Testamento: San Pablo, en la primera Carta a los Corintios, les dice a estos que «ha sido inmolado nuestro cordero pascual: Cristo» $(1$ Cor 5,7$)$ y el Apocalipsis $(5,8$ 14) ahonda en la expresión de este motivo.

Nicanor Parra lo retoma en su poema "Cordero pascual", de Canciones rusas (1967), y en "Agnus Dei" ${ }^{17}$, de Obra gruesa, un par de años después. El primero pide el asesinato de este cordero "para que el ser humano coma carne"; el poeta juega con la significación material de este icono religioso, que, a fin de cuentas, es un animal que sirve de alimento, así como con su dimensión simbólica: matar al cordero pascual supone matar una religión, una tradición hondamente arraigada, por más que no debamos olvidar que "es un simple cordero / el que se está matando". Parra explicita la connotación religiosa del suceso, pero lo hace desde una visión panteísta:
Y no lo comamos con el ceño fruncido
Sino con gran respeto.
Casi con sentimiento religioso.
Y después del banquete
Demos las gracias al sistema solar.

“Agnus Dei”, por su parte, procede de la concepción cristiana del motivo del cordero pascual. En el Evangelio según san Juan es donde aparece por primera vez esta expresión que ha devenido en oración litúrgica: "Al día siguiente, Juan ve a Jesús que viene hacia él, y entonces dice: «Este es el Cordero de Dios, el que quita el pecado del mundo»" (Jn 1, 29). El poema la parodia, adjuntándole a esta coletilla elementos chocantes y humorísticos que, una vez más, desatan la carcajada o, al menos, dibujan una sonrisa en el rostro. En este caso particular, el efecto es, si cabe, más sorprendente, ya

${ }^{17}$ N. Parra (2006), pp. 166 y 186, respectivamente. 
que la primera parte del poema transluce un tono mucho más sombrío y en ella la tierra es el elemento fundamental. Lo espiritual queda, pues, de lado y ello desemboca en la siguiente antítesis: "Alma inmortal — espíritu de tierra".

Pero una vez que sienta las bases de su estrecha vinculación con lo terrenal, Parra comienza su oración, su peculiar miserere nobis, en el cual no pide perdón por los pecados cometidos, sino cosas mucho más materiales en las que queda clara la vinculación con el poema que antes comentaba: "Cordero de dios que lavas los pecados del mundo / dame tu lana para hacerme un sweater". Antes pedía carne, ahora lana; el caso es hacer del icono algo útil, algo verdaderamente primordial, algo que sirva en un mundo postcristiano. "Agnus Dei" finaliza también con una mención a lo religioso, a lo sagrado, pero que aquí - igual que antes estaba representado por lo panteísta - se encarna en el acto sexual: "Cordero de dios que lavas los pecados del mundo / déjanos fornicar tranquilamente: / no te inmiscuyas en ese momento sagrado". La destrucción de los grandes símbolos conlleva el ensalzamiento de nuevos ídolos, excluidos anteriormente del altar de lo sagrado. Parra lleva a cabo la inversión de lo sacro y lo profano.

En cuanto a la influencia del Nuevo Testamento en la poesía de Nicanor Parra, habremos de hablar de ciertos personajes evangélicos que pueblan sus versos: uno de ellos es Lázaro de Betania, el resucitado hermano de María y Marta, cuya historia es narrada en el Evangelio según san Juan. Famosa es la sentencia "Levántate y anda" que Jesús pronuncia al muerto Lázaro, una vez que ha hecho retirar la losa de su sepulcro. Esta sentencia forma parte de uno de sus artefactos visuales, donde su significado parece más bien un "Levántate y actúa". Una vez más vemos ahí al poeta que pretende sacar al lector de su ensimismamiento.

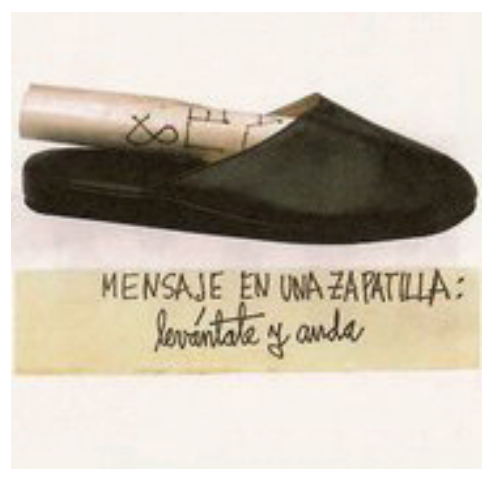

Pero es el poema "El anti-Lázaro" (1981) el que recupera el episodio bíblico con una mayor viveza, aunque, claro está en el título, posicionándose en el lado opuesto. En él, la voz poética le pide a Lázaro - o más bien a un muerto cuyo nombre, en realidad, no se especifica - que no se levante de la tumba, que no resucite, que sea feliz en su sepulcro. La vida terrenal es considerada "el infierno de Dante", un lugar 
plagado de enigmas y arbitrariedades, de dolores, orgullo, sangre, avaricia. ¿Para qué resucitar entonces? Por ello, con tino, insta al muerto a que no se levante bajo ningún concepto, a que disfrute del amor que le profesa la tierra y siga durmiendo, tranquilo, al amparo de las tropelías de este mundo:

sigue durmiendo hombre sigue durmiendo
sin los aguijonazos de la duda
amo y señor de tu propio ataúd
en la quietud de la noche perfecta
libre de pelo y paja
como si nunca hubieras estado despierto
no resucites por ningún motivo
no tienes para qué ponerte nervioso
como dijo el poeta
tienes toda la muerte por delante

Otro de los personajes evangélicos, este apenas esbozado por san Lucas, es el Buen Ladrón, a quien se le llama Dimas en los Evangelios apócrifos, y en cuya boca se pone la siguiente frase: “¡Jesús acuérdate de mí cuando llegues a tu reino!" (Lc 23,42). Las peticiones del Dimas al que Parra le da voz en su poema "Discurso del Buen Ladrón" se inician, precisamente, con esa frase, pero este continúa pidiendo puestos y nombramientos a su antiguo compañero de ejecución, sin conformarse con un mero recuerdo por su parte, insinuándose un trepa que intenta ascender gracias a la religión:

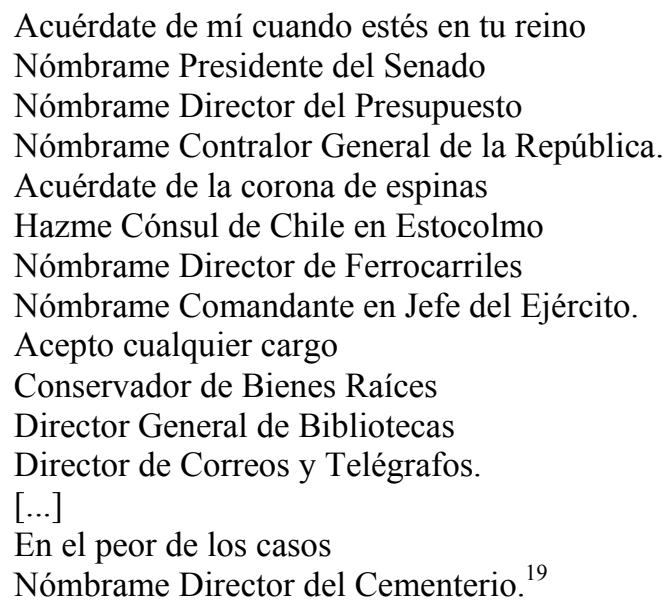

\footnotetext{
${ }^{18}$ N. Parra (2011), p. 80.

${ }^{19}$ N. Parra (2006), p. 187.
} 
Este último poema, ambientado en la crucifixión, enlaza con el siguiente de los temas principales de Nicanor Parra, al menos en lo tocante a la Biblia y el imaginario cristiano: la cruz.

\section{De crucifixiones, crucificados y cruces}

El símbolo de la cruz es, probablemente, el motivo bíblico que acoge más reformulaciones y variantes dentro de la poesía de Parra, pues, aparte de recibir una atención especial y una recurrencia mayor que los motivos anteriormente señalados, se expresa en poemas de diferente signo y con diferentes propósitos. La cruz es, para Parra, como expresa en el poema homónimo incluido en Obra gruesa un símbolo dotado de un atractivo carente por el momento de significado para él, pero que alguna vez lo obtendrá, a lo cual el poeta se resiste.

Tarde o temprano llegará sollozando a los brazos abiertos de la cruz.

Más temprano que tarde caeré de rodillas a los pies de la cruz;

Tengo que resistirme para no desposarme con la cruz; ¡ven cómo ella me tiende los brazos? No será hoy

mañana

mañana

ni pasado

pero será lo que tiene que ser.

Por ahora la cruz es un avión.

una mujer con las piernas abiertas. ${ }^{20}$

El poeta juega también a imaginar el episodio de la crucifixión, por ejemplo, en el poema XVI del Discurso del Caupolicán $(1993)^{21}$, donde relata cómo se topó con la subida a la cruz de un hombre de unos treinta años, "esquelético y melenudo", a quien le lloraba una tal Magdalena. "¿No sintió nada fuera de lo común?”, le preguntan, y él solo puede responder que lo que sintió fue curiosidad. La curiosidad de un ateo no implicado en el cristianismo, pero que se interroga, interroga a su entorno, antes de rechazar de plano. La misma actitud curiosa que desvela en cada uno de estos poemas subversivos. Pero, además, la crucifixión - al igual que los Evangelios, al igual que todo lo tocado por la varita poética de Nicanor Parra- puede tener también su veta humorística. Así sucede en un poema incluido en Hojas de Parra (1985), en el que la conversión religiosa del creyente se produce justamente a partir del humor:

${ }^{20}$ N. Parra (2006), p. 202.
${ }^{21}$ N. Parra (2011), p. 627. 


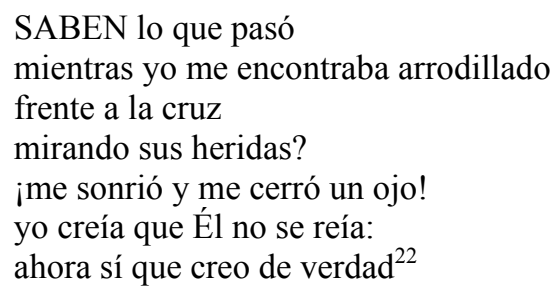

Pero más allá de estos poemas más tradicionales, encontramos poemas visuales en los que el chileno experimenta con las posibilidades del símbolo iconográfico por excelencia del cristianismo. Por un lado, está el artefacto visual escogido por los editores de Galaxia Gutenberg para figurar en la contratapa de sus obras completas: una cruz de madera de la que, como si de una ventanilla de la Administración pública se tratara, cuelga un cartel en el que está escrito "Voy \& vuelvo". Cartel que en dicha ventanilla o en la puerta de cualquier establecimiento no sorprendería, pero cuyo contexto de aparición lo condiciona terriblemente; ese mismo cartel, colgado, de una cruz de madera, se convierte en una humorada sobre la resurrección. Con una imagen y apenas un par de palabras, el maestro Parra consigue cuestionar - $\mathrm{O}$ retratar, si se quiere - uno de los más importantes dogmas del catolicismo. Impactante y directo.

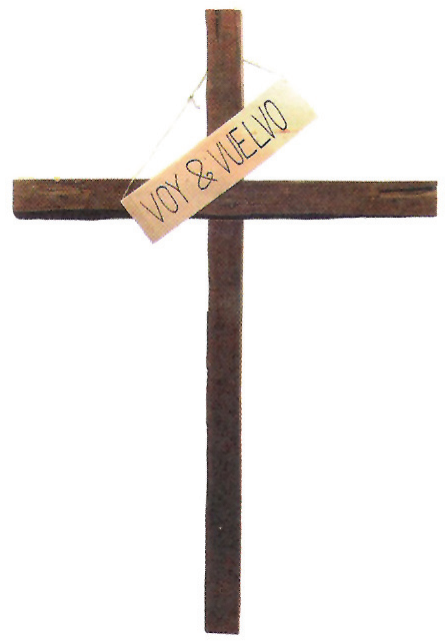

${ }^{22}$ N. Parra (2011), p. 294. 
Otra experimentación con lo visual está en "Los cuatro sonetos del Apocalipsis"23, donde la composición estrófica tradicional, aparte de producir una sutil paronomasia jinetes-sonetos, sirve para insertar en ella elementos visuales que subvierten el concepto tradicional de soneto. Este, recordemos, consta de catorce versos, normalmente endecasílabos, repartidos en dos cuartetos y dos tercetos. Los apocalípticos sonetos de Parra respetan el patrón, pero introducen una particularidad: el lenguaje desaparece y cede su lugar a la cruz. ¿Deseo de callar o de decir aquello que las palabras no pueden transmitir? El icono sustituye al lenguaje, como queriendo dar cuenta de algo más grande que el silencio. Silencio, eso sí, plagado de cruces.

\section{5. "Pater noster, qui es in caelis..."}

Por último, pero no menos importante, hablar de la relación entre Nicanor Parra y la religión católica supone hablar de sus versiones de la oración más conocida y probablemente rezada de esta: el padrenuestro. Dos variantes, cuyas divergencias son mínimas, aparecen en los Evangelios (Mt 6, 9-13 y Lc 11, 2-4) y dos variantes aparecen también en la poesía parriana; la primera de ellas perteneciente a Obra gruesa:

Padre nuestro que estás en el cielo

Lleno de toda clase de problemas

Con el ceño fruncido

Como si fueras un hombre vulgar y corriente

No pienses más en nosotros.

Comprendemos que sufres

Porque no puedes arreglar las cosas.

Sabemos que el Demonio no te deja tranquilo

Desconstruyendo lo que tú construyes.

El se ríe de ti

Pero nosotros lloramos contigo:

No te preocupes de sus risas diabólicas.

Padre nuestro que estás donde estás

Rodeado de ángeles desleales

Sinceramente: no sufras más por nosotros

Tienes que darte cuenta

De que los dioses no son infalibles

Y que nosotros perdonamos todo. ${ }^{24}$

La inversión de las creencias o valores cristianos es patente en este "Padre nuestro", que trata con tremenda conmiseración a un Dios en absoluto todopoderoso. El símil se evidencia desde el comienzo ("como si fueras un hombre vulgar y corriente"),

\footnotetext{
${ }^{23}$ N. Parra (2011), pp. 240-243.

${ }^{24}$ N. Parra (2006), p. 185
} 
pero el como atenúa una identificación que es clara. La voz poética retrata a Dios como un hombre absolutamente vulgar y corriente, que sufre y siente impotencia, mientras que sus "ángeles desleales", el Demonio entre ellos, boicotean lo que él construye. Es dicha voz quien asume un papel paternal frente a ese Dios al que, en efecto, llama padre, y le insta a no preocuparse, a dejar todo en sus manos.

Inevitable es ver en este ejemplo el destierro de la religión como asidero. El destino humano no puede ser conducido sino por los propios humanos, y los dioses que no son infalibles, declara Nicanor- se prestan a recibir el perdón de sus criaturas, benevolentes hacia los problemas que él mismo ha ocasionado. El creyente ya no reza, no le suplica a su Dios; le pide más bien que se quede quieto, esperando a que sus hijos emancipados arreglen el desaguisado en el que los ha sumido, porque ellos, aun sin recibir súplicas por su parte, lo perdonan todo.

El siguiente padrenuestro de Parra es producto de un paso más allá, de una experimentación si cabe mayor que la que ya había en los artefactos visuales o en "Los cuatro sonetos del Apocalipsis". Así, le declara a Leónidas Morales:

Tengo que mostrar un poema que se llama "Padre Nuestro", y que no consiste nada más que en el texto del Padre Nuestro, tal como lo aprendimos nosotros en el colegio o en la casa. Pero tú lo que haces es subrayar unas letras, ponerlas con mayúscula realmente, de manera que resalten del texto. Si miras el texto, así, de lejos, entonces lo que tú ves simplemente es Tome Coca-Cola. Eso es lo que resalta.

En este poema ya no hay casi creación, sino más bien aprovechamiento del material legado por la tradición: la consabida oración cristiana sirve de punto de partida para un alegato publicitario en provecho de la Coca-Cola y lo hace solo con una disposición particular de los versos y las letras y un simple resalte en mayúsculas de algunas de ellas. Así de sencillo. La antigua religión cristiana es sustituida por la nueva religión de la posmodernidad: el consumo capitalista y globalizado. Y todo ello sin apenas esfuerzo, solo sabiendo mirar un mensaje escrito entre líneas.

Este último "Padre Nuestro" supone también un paso adelante en la despersonalización del sujeto, que ya no requiere ni siquiera la adopción de una máscara que lo convierta en fantoche o energúmeno. En él, "desaparece no tan sólo el hombre, el sujeto, sino que desaparece el hablante lírico también" 25 , pues este no se necesita cuando se puede tomar prestado de un discurso ajeno. No se necesita lírica para decir "Tome Coca-Cola": la publicidad ha dinamitado la poesía.

${ }^{25}$ L. Morales, (1992), p. 138 y 139. 


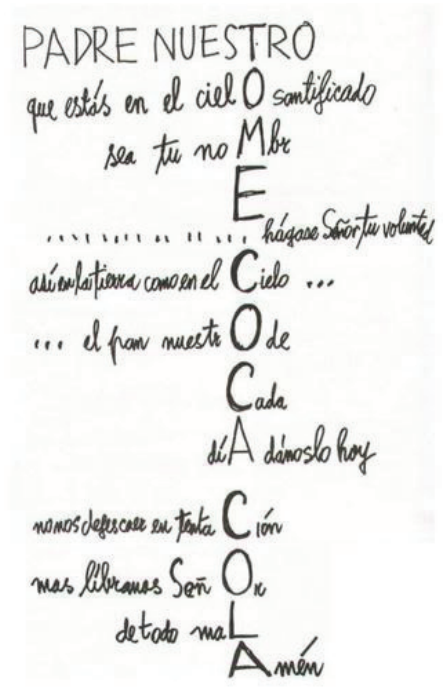

"No sé si Dios ha muerto, pero mi misión es matarlo", parece decir Parra con cada uno de los versos aquí consignados, con sus humoradas, sus ceños fruncidos y sus sonrisas de medio lado. El intertexto bíblico tiene en su poesía la función subversiva de destruir uno de los grandes relatos de la modernidad y rematar al Dios (y a sus secuaces) que ya había sido liquidado, en teoría, décadas antes. "No sé si Dios ha muerto, pero si hay que matarlo, que sea a carcajadas", parece decir, y sus poemas, sus artefactos, sus experimentos, nos instan a mirar la tradición desde la risa, risa seria que despierta del letargo. A mirar desde ahí la Biblia, libro tan verdadero como hermoso como falso. A levantarnos y andar.

\section{OBRAS CITADAS}

BINNS, Niall: Postmodernidad en la poesía chilena contemporánea (Nicanor Parra, Jorge Teillier, Enrique Lihn), tesis doctoral del departamento de Filología Española IV de la Universidad Complutense de Madrid, leída el 16-I-1997

$<$ http://eprints.ucm.es/tesis/19972000/H/3/H3053501.pdf>

GARCÍA, Javier: "Raúl Zurita: «La poesía emerge de Dios»”, La Nación, 4-IV-2010 $<$ http://www.lanacion.cl/raul-zurita-la-poesia-emerge-de-dios-/noticias/2010-0403/181612.html>

LYOTARD, Jean-François: La condición postmoderna. Informe sobre el saber, Madrid, Cátedra, 2008.

MiLlARES, Selena: "La antipoesía de Nicanor Parra, en las barricadas de la contracultura", De Vallejo a Gelman: un siglo de poetas para Hispanoamérica, Universidad de Alicante, Cuadernos de América sin nombre, 2011, pp. 81-96. 
Morales, Leónidas: Conversaciones con Nicanor Parra, Santiago de Chile, Editorial Universitaria, 1992.

PARRA, Nicanor: Obras completas I \& algo † (1935-1972), Barcelona, Galaxia Gutenberg, 2006.

Obras completas II \& algo † (1935-1972), Barcelona, Galaxia Gutenberg, 2011. 